\title{
Unusual metastatic spread of bladder cancer
}

\author{
Rachel Garth, ${ }^{1}$ Vinay Sathyanarayana, ${ }^{2}$ Kapil Kapur ${ }^{1}$
}

1 Department of

Gastroenterology, Barnsley District General Hospital,

Barnsley, South Yorkshire, UK ${ }^{2}$ Department of

Gastroenterology, Barnsley Hospitals NHS Foundation

Trust, Barnsley, South

Yorkshire, UK

\section{Correspondence to}

Dr Vinay Sathyanarayana, vsathyanarayana@nhs.net

Accepted 31 August 2014

\section{(a) CrossMark}

To cite: Garth R, Sathyanarayana V, Kapur K. BMJ Case Rep Published online: [please include Day Month Year] doi:10.1136/ bcr-2014-206013

\section{DESCRIPTION}

A 67-year-old man was admitted by his GP with general deterioration. He had a history of stroke with residual left-sided weakness and squamous cell carcinoma of the bladder (T2 N0 R0) diagnosed 1 year prior to admission, he had undergone radical cystoprostatectomy. The vital signs were stable and there were no specific features from the history or on examination. On admission routine bloods showed hypercalcaemia $\left(\mathrm{Ca}^{2+}: 2.98\right)$ which was treated with intravenous fluid therapy and bisphosphonates.

At the point of diagnosis the bladder tumour was muscle invasive within the bladder wall with no lymphadenopathy, the patient underwent radical

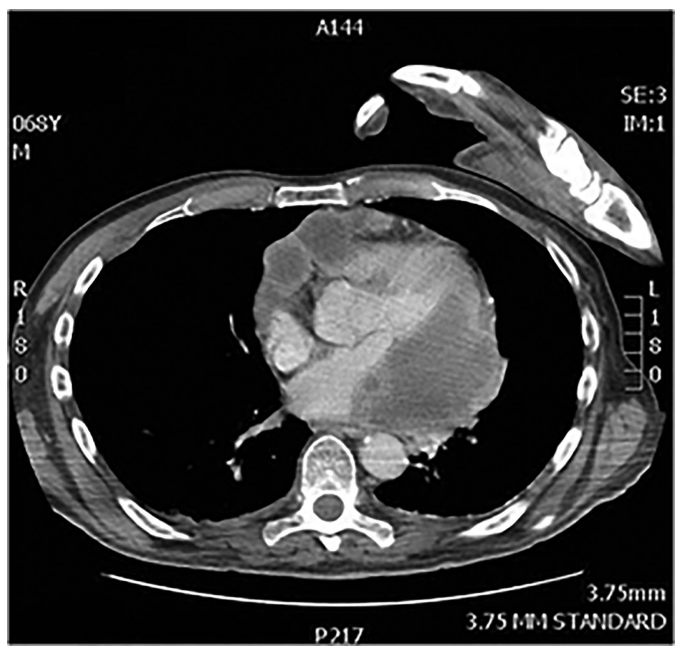

Figure 1 Pericardial metastases on CT scan. cystoprostatectomy with resection of the lymph nodes and creation of an ileal loop bladder, he had an uncomplicated recovery from this surgery and adjuvant treatment was not offered.

The hypercalcaemia was investigated further; the bone scan did not show any evidence of bony metastasis. The CT of the abdomen demonstrated multiple enhancing nodules in the pericardium (figure 1). The subsequent echocardiogram confirmed the presence of a tissue mass in the right ventricle and pericardium.

The case was discussed at the urology multidisciplinary team where it was decided that the patient would be for best supportive care due to the extensive metastasis of the malignancy. The patient continued to deteriorate and was supported by the end-of-life care pathway during the last days of life.

\section{Learning points}

- This case demonstrates that cancer does not always follow the usual pattern of metastasis.

- Hypercalcemia in a patient with known squamous cell cancer should prompt one to look for metastatic spread.

- The pattern of metastasis seen in this patient had not been seen previously by the team and no similar reports have been found from literature search.

\section{Competing interests None.}

Patient consent None.

Provenance and peer review Not commissioned; externally pee reviewed.

Copyright 2014 BMJ Publishing Group. All rights reserved. For permission to reuse any of this content visit http://group.bmj.com/group/rights-licensing/permissions.

BMJ Case Report Fellows may re-use this article for personal use and teaching without any further permission.

Become a Fellow of BMJ Case Reports today and you can

- Submit as many cases as you like

- Enjoy fast sympathetic peer review and rapid publication of accepted articles

- Access all the published articles

- Re-use any of the published material for personal use and teaching without further permission

For information on Institutional Fellowships contact consortiasales@bmjgroup.com

Visit casereports.bmj.com for more articles like this and to become a Fellow 